OPEN ACCESS

Edited by:

Yizi Shang,

China Institute of Water Resources and Hydropower Research, China

Reviewed by: Carly Maynard, Scotland's Rural College,

United Kingdom

Paria Shojaei,

Isfahan University of Technology, Iran

*Correspondence:

Diana Carolina Callejas Moncaleano d.c.callejasmoncaleano-1@tudelft.nl

Specialty section:

This article was submitted to Water and Human Systems,

a section of the journal

Frontiers in Water

Received: 25 March 2021

Accepted: 12 July 2021

Published: 05 August 2021

Citation:

Callejas Moncaleano DC, Pande S and Rietveld L (2021) Water Use Efficiency: A Review of Contextual and Behavioral Factors.

Front. Water 3:685650. doi: 10.3389/frwa.2021.685650

\section{Water Use Efficiency: A Review of Contextual and Behavioral Factors}

\author{
Diana Carolina Callejas Moncaleano*, Saket Pande and Luuk Rietveld \\ Department of Water Management, Faculty of Civil Engineering and Geosciencies, Delft University of Technology, Delft, \\ Netherlands
}

Water withdrawals around the world have increased almost twice as fast as the population during the last century. Higher than expected water demand is leading to water scarcity and causing rapid depletion of water tables around the world. One reason behind the higher than expected demand is the inefficient use of water. Inefficient use of water affects the well-being of society, the economic stability of countries, and environmental health. Indeed, water use efficiency (WUE) is one of the pillars of sustainable development goals (SDG 6.4.1). However, progress toward achieving WUE is slow, especially for many developing countries where the degradation of natural resources is critical, economic growth is slow, and there are few strong institutions to coordinate actions. One reason behind inefficient water use is human behavior. A variety of contextual and psychological factors underlie the behavior. The contextual factors include socioeconomic, technical, institutional, and environmental factors and the behavioral factors include factors associated with the perception of risk, attitudes, norms, etc. Yet, few studies consider an integrated view of these factors in shaping water use behavior. This paper consolidates contextual and behavioral factors which influence water use, studies the gaps in our understanding of human water behavior underlying WUE and highlights the need to comprehensive assess and consistently measure such factors and their relationships. Based on the gaps identified, it proposes a conceptual model that connects contextual and behavioral factors and represents potential cause-effect relationships as supported by various environmental behavior approaches and psychological theories. Based on the literature review of water use, and conservation behavior, environmental psychology, and water use models, this model proposes an institutional factor to assess the relationship between institutions and stakeholders, and study contextual factors linked not only for individual water users but also studying these factors for individuals of water supply organizations.

Keywords: water use efficiency, human behavior, contextual factors, psychological factors, behavioral factors

\section{INTRODUCTION}

Every day large amounts of water are extracted from inland surface water bodies (e.g., rivers, lakes, wetlands, and reservoirs) and aquifers for diverse uses such as for agriculture, domestic, electricity, and industrial purposes. Water withdrawal around the world has increased almost twice as fast as the world population (FAO, n.d.). Agriculture is the largest water using sector, accounting for approximately $69 \%$ of global water withdrawals, whereas municipal withdrawals contribute to $12 \%$ of total withdrawals (FAO, 2018b). Withdrawing water faster than it is recharged 
has led to water scarcity in countries such as Qatar, Saudi Arabia, and Pakistan, which are suffering from extremely high water stress conditions (Hofste et al., 2019). This, when combined with weak control of water permissions and concession rights, has exasperated water scarcity.

The difference between global water withdrawals and real water demand is significant and is steadily increasing. One of the reasons behind this difference is the inefficient use of water, leading to consumption that can otherwise be lower (Wang et al., 2015; Nazari et al., 2018; Ding et al., 2019; Ghanim, 2019). The resulting over-extraction poses considerable risks to water sustainability as rivers and groundwater resources around the world are running dry (Jorgensen et al., 2009; Graymore and Wallis, 2010; Arto et al., 2016; Bhaduri et al., 2016; Mekonnen and Hoekstra, 2016; Lund et al., 2018).

Driven by unconstrained consumption, water scarcity could occur even under average climate conditions. Inefficient use of water also affects the provision of environmental flows and contributes to environmental degradation and economic instability (Mekonnen and Hoekstra, 2016; Vieira et al., 2017; Piedra-Muñoz et al., 2018). Efficient use of water has therefore often been proposed as a measure by policymakers and water managers to reduce the inflated gap between water extractions and water demand.

Efficient use of water conserves water and reduces pressure over natural sources. By reducing water consumption, water flows in water treatment plants and irrigation systems diminish (Tang et al., 2013; Jorgensen and Martin, 2015), leading subsequently to reductions in effluent discharges (Hoekstra, 2014). It thus also contributes to environmental and economic benefits (Rad et al., 2019) such as water protection, and reduction in operational costs (See, 2015; Jabari, 2017).

Therefore, water users and institutions have taken actions toward improving water use efficiency (WUE) (Bruneau et al., 2013). Global and local policies, aiming at reducing water demand, have focused mainly on two sectors with a relatively high number of users and relevant for water security: households (Attari, 2014; Manouseli et al., 2019), and farmers (Bruneau et al., 2013; Tang et al., 2013; Chang et al., 2016; Roobavannan et al., 2017; Benito et al., 2019; Ghanim, 2019; Xiao et al., 2019), farmers being the biggest water user. Actions include installation of water-saving devices, leakage control, water re-use, water harvesting, implementation of indicators like non-revenue water (NRW), and the extension of economic incentives to users, such as increasing water price, and subsidies to water savers (Wang et al., 2015; Chang et al., 2016).

Increasing WUE is also one of the pillars of those global and local policies, such as the SDGs of the United Nations (Cole et al., 2018; Ortigara et al., 2018). In addition, the strategy of the European Commission (EU, 2014) is to move from a linear economy to a sustainable, circular economy by 2050 . Moreover, the national water initiative of Australia (Department of Agriculture, 2019) is pursuing WUE to conserve rivers and groundwater systems, Colombia's Government has established plans to improve WUE in their policy plan (Minambiente, 2010), and the United States Environmental Protection Agency (USEPA) is implementing WUE strategies to mitigate water stress and prevent water conflicts (GAO-14-430, 2014; EPA, 2018).

Despite such efforts, the slow progress of the application of WUE principles remains a matter of concern for many developing countries where natural resources are being critically degraded, and the economic growth is slow compared to developed countries (Sánchez et al., 2004; Carrus et al., 2010; Russell and Fielding, 2010; Bruneau et al., 2013; Jorge et al., 2015; Mekonnen and Hoekstra, 2016; Rad et al., 2019). Often WUE is only associated with technical factors that affect the performance of water utilities, e.g., water leakages in water distribution systems, poor management, and maintenance of irrigation systems (European Environment Agency, EEA, 2007). Other factors such as those linked to the psychology of water use, influencing behavior, and decisions of relevant water users, are frequently ignored by policymakers. Mosler (2012) defines behavior as the result of the psychological processing of factors within the individual. Therefore, a comprehensive assessment of these factors and their relationships is needed to provide insights into the causes of over-extraction, the interdependence between stakeholders, and the effects on WUE.

A holistic view of how various such factors influence WUE behavior is currently not available. Therefore, this contribution aims to identify challenges in understanding water use behavior, especially underlying WUE, while considering various contextual and behavioral factors. Based on gaps that are identified, a conceptual model is proposed to capture the relationship between institutions and stakeholders, and studies contextual factors linked not only of individual water users but also studying these factors for individuals of water supply organizations to understand (in)efficient water use.

\section{WATER USE EFFICIENCY CONCEPT Definition of Water Use Efficiency}

The WUE concept has been extended to environmental sustainability, sustainable development, and water management frameworks. As summarized in Table 1, WUE is interpreted differently in different uses of water (e.g., agriculture, industry, and service sectors). Activities linked to water use, therefore, pursue different WUE targets. However, only few frameworks have focused on WUE as an alternative to water protection and conservation.

\section{Approaches to Achieve WUE}

Since the concept of WUE involves various definitions, approaches, and indicators, it has implications on water literacy (Dean et al., 2016), specifically WUE knowledge. It means how WUE is interpreted and implemented by various water users.

There are numerous approaches available to achieve WUE (Gleick et al., 2011). Each such approach depends on specific objectives, Table 2 summarizes the most important approaches that refer to WUE. For example, water conservation and mitigation of scarcity can motivate efficient water use practices to meet specific environmental goals. Expanding existing production, profit maximization, and costs minimization efforts prompt producers to use water 
TABLE 1 | Diverse interpretations of WUE.

\begin{tabular}{|c|c|c|}
\hline Domain & Interpretation & Reference \\
\hline \multirow[t]{2}{*}{ Agronomy } & Crop production per unit volume used. & Stanhill, 1986; Howell, 2005 \\
\hline & The water efficiency is the ratio between water used and water withdrawals. & UN, 2015; FAO, 2018a \\
\hline \multirow[t]{4}{*}{ Sustainability } & $\begin{array}{l}\text { WUE in any activity is related to using the resource in a better way, doing more or the same with less } \\
\text { quantity. }\end{array}$ & Sánchez et al., 2004 \\
\hline & Resource efficiency refers to water consumption per unit of process or product. & Hoekstra et al., 2017 \\
\hline & $\begin{array}{l}\text { Actions focus on reducing water consumption, and leakages, or optimizing water usage. These actions } \\
\text { include water reuse, recycling, rain usage, controlling leakages, and moving to saving technologies. }\end{array}$ & Minambiente, 2018 \\
\hline & Using the Earth's limited resources sustainably while minimizing the impacts on the environment. & European Union, 2019 \\
\hline Water management & It is a term used to measure the productivity of water used for specific purposes. & Brooks, 2006 \\
\hline Technical & $\begin{array}{l}\text { Innovation based, moving to water saving systems, e.g., moving from flood irrigation to sprinkler } \\
\text { systems, and from high to low-pressure systems. }\end{array}$ & Bruneau et al., 2013 \\
\hline
\end{tabular}

TABLE 2 | Approaches toward improving WUE.

\begin{tabular}{|c|c|c|c|c|}
\hline Domain & $\begin{array}{l}\text { Principles guiding } \\
\text { water use }\end{array}$ & Definition of/approach toward WUE & Motivation & Reference \\
\hline \multirow[t]{2}{*}{$\begin{array}{l}\text { Sustainable development } \\
\text { goals (SDG) }\end{array}$} & $\begin{array}{l}\text { Economic, } \\
\text { Sustainability }\end{array}$ & $\begin{array}{l}\text { Development that meets the needs of the } \\
\text { present without compromising the ability of } \\
\text { future generations to meet their own needs. }\end{array}$ & $\begin{array}{l}\text { Economic viability } \\
\text { Protection of the environment } \\
\text { Social and ethical acceptance }\end{array}$ & Hens et al., 2018 \\
\hline & & $\begin{array}{l}\text { Goal 6.4.: Increasing water-use efficiency } \\
\text { across all sectors and ensure sustainable } \\
\text { withdrawals and supply of freshwater. } \\
\text { Improving water efficiency means water-saving } \\
\text { and making water available for other purposes. }\end{array}$ & $\begin{array}{l}\text { Addressing water scarcity } \\
\text { Increasing water availability for } \\
\text { people and the economy }\end{array}$ & $\begin{array}{l}\text { UN, 2015; Ortigara et al., } \\
2018\end{array}$ \\
\hline \multirow[t]{2}{*}{ Cleaner production $(\mathrm{CP})$} & Economic & $\begin{array}{l}\text { Integrate preventive environmental strategies to } \\
\text { processes, products, and services to increase } \\
\text { efficiency and reduce the risk to humans and } \\
\text { the environment. }\end{array}$ & $\begin{array}{l}\text { Environmental sustainability } \\
\text { Maximization of water reduction } \\
\text { Recycling } \\
\text { Reuse }\end{array}$ & Hens et al., 2018 \\
\hline & & $\begin{array}{l}\text { Resource use minimization, } \\
\text { improved eco-efficiency, } \\
\text { environmental protection. }\end{array}$ & Doing more with less & Glavič and Lukman, 2007 \\
\hline Circular Economy (CE) & Economic & Minimizing the intake of fresh raw materials. & $\begin{array}{l}\text { 3Rs (reduce, reuse, recycle) } \\
\text { Closing the loop of use of resources }\end{array}$ & $\begin{array}{l}\text { Winans et al., 2017; } \\
\text { Varbanov and Walmsley, } \\
2019\end{array}$ \\
\hline $\begin{array}{l}\text { Sustainable water } \\
\text { management (SWM) } \\
\text { efficiency }\end{array}$ & $\begin{array}{l}\text { Social, } \\
\text { Environmental, } \\
\text { Economic, } \\
\text { Technical }\end{array}$ & $\begin{array}{l}\text { Balancing water resources supply with } \\
\text { demands from society, economy, and } \\
\text { the environment. }\end{array}$ & $\begin{array}{l}\text { Sustainable water } \\
\text { management (SWM) }\end{array}$ & Zhang and Xu, 2019 \\
\hline Water footprint & $\begin{array}{l}\text { Sustainability, } \\
\text { Economic }\end{array}$ & $\begin{array}{l}\text { Analyzing water usage along supply chains, } \\
\text { and assessing the sustainability, efficiency, and } \\
\text { fairness of its water use. }\end{array}$ & Reduction of water consumption & Hoekstra, 2014 \\
\hline Blue water footprint & $\begin{array}{l}\text { Sustainability, } \\
\text { Economic }\end{array}$ & $\begin{array}{l}\text { Measuring the consumption of groundwater or } \\
\text { surface water. }\end{array}$ & $\begin{array}{l}\text { The assessment of freshwater use } \\
\text { and its relation to consumption, } \\
\text { production, and trade }\end{array}$ & Hoekstra et al., 2017 \\
\hline
\end{tabular}

more efficiently (Bruneau et al., 2013). It may also be motivated by consumer or regulators demands for cleaner production, lower water footprint (Mekonnen et al., 2015), and circular economy (Winans et al., 2017; Varbanov and Walmsley, 2019).

Reduction of water footprint implicitly measures the effect of reducing water usage on water scarcity (Hoekstra, 2014). In the context of sustainable water management, efficient water use aims at finding a balance between water resources availability and demands from society, the economy, and the environment (Zhang and $\mathrm{Xu}, 2019)$. The circular economy, on the other hand, involves the reduction of water use, water reuse, and recycling schemes and implies closing the loop of resource usage (Winans et al., 2017).

Therefore, calculating WUE for a particular use depends on how WUE is interpreted, how specific variables are used, availability of reliable data, and if data tally with the variables. Experts who have developed a methodology to compute indicator 6.4.1. of SDGs, related to water-use efficiency, mention that "different sectors require their definition of water-use efficiency" (FAO, 2018a). 
TABLE 3 | Indicators related to WUE.

\begin{tabular}{|c|c|c|}
\hline Indicator/Index & Description & Reference \\
\hline WUE 6.4.1. (SDG) & $\begin{array}{l}\text { Change in water-use efficiency over time. It is an economic component of SDG target 6.4. and } \\
\text { evaluates to what extent a country's economic growth is dependent on the use of water } \\
\text { resources. It can be calculated at national and basin scales. }\end{array}$ & UN, 2015; FAO, 2018a \\
\hline Blue water footprint & $\begin{array}{l}\text { It is an indicator of direct and indirect freshwater use by a consumer or producer. It gives } \\
\text { information about how much water is being consumed by a particular country at river or } \\
\text { catchment scale. } \\
\text { It can be calculated for a particular process, product, and company. It is computed as the } \\
\text { volume of water abstracted from natural sources minus the water returned to the system. }\end{array}$ & $\begin{array}{l}\text { Hoekstra, 2014; Water } \\
\text { footprint, n.d. }\end{array}$ \\
\hline Water exploitation index (WEI) & $\begin{array}{l}\text { Measuring the ratio between the mean annual total freshwater abstraction and the long-term } \\
\text { average of available freshwater resources. The unit of measure is a percentage. }\end{array}$ & European Union, 2019 \\
\hline Water productivity index (WPI) & $\begin{array}{l}\text { Measuring the amount of economic output produced (EUR) in terms of gross domestic product } \\
\text { (GDP) per unit of water abstracted }\left(\mathrm{m}^{3}\right) \text {. } \\
\text { The WEI and WPI indices aim at monitoring WUE at national scale through sustainable water } \\
\text { usage and reduced pressure over natural water sources. }\end{array}$ & European Union, 2019 \\
\hline WUE evaluation index system & $\begin{array}{l}\text { It is a method used in sustainable water management efficiency (SWM) evaluation, and it aims } \\
\text { to evaluate regional sustainable water utilization. } \\
\text { The index considers the experts' psychological factors in the decision-making processes, and } \\
\text { uses six indicators. }\end{array}$ & Zhang and Xu, 2019 \\
\hline
\end{tabular}

The indicators used to estimate WUE vary with temporal and spatial scales of water use and users, depending on the variables and methodology used for its estimation, and the target stakeholders (FAO, 2018a). Table 3 presents various indicators that have been used to analyze water usage related to WUE.

Hoekstra et al. (2017) state that "looking at efficiency from the production perspective is limited because most of the reduction of water consumption can be achieved by changing consumption patterns." In the assessment of WUE indicator 6.4.1. of SDGs, institutions play an essential role in coordinating various stakeholders who are involved in monitoring the indicator (FAO, 2018a).

Details on how various variables are measured and its effects estimated are often not clear. Bhaduri et al. (2016) state that "the level of allowable withdrawal rates from freshwater bodies is not well established scientifically;" Hák et al. (2016) and Miola and Schiltz (2019) show there is no clear link between methods and indicators used to measure the performance of SDGs. Zhang and Xu (2019) claim that "the absence of an effective, scientific evaluation method may lead to a lack of awareness of sustainable water usage."

Approaches to assess and achieve WUE influence and is influenced by, the knowledge and capacity of water users to adopt best practices. These, in turn, affect behavioral factors such as attitudes and perceptions of individuals and influence their decisions about water use.

\section{FACTORS UNDERLYING WATER USE BEHAVIOR}

In the context of water use, water use behavior is defined as an environmental behavior. Steg and de Groot (2018) define environmental behavior as "any behavior that has a good or bad impact on the environment" (p. 164). This behavior is influenced by contextual and behavioral factors (Carrus et al., 2010; Graymore et al., 2010; Russell and Fielding, 2010).

Contextual factors refer to the background characteristics of individuals and their physical environment (Dreibelbis et al., 2013). These influence behavioral factors in different ways (Contzen and Mosler, 2012) and may facilitate or constrain behaviors. The contextual factors encompass social, economic, technical, environmental, and institutional backgrounds, acquired skills, immediate personal conditions, economic resources, capabilities, regulations, etc. The first three factors have been shown to be important in predicting water use (Russell et al., 2020). Here, the environmental factors refer to geographical experiences which are connected with associative learning (Dean et al., 2016), and institutional factors involve institutional relationships (Kapetas et al., 2019) between water users and the water supply systems and regulations (Khair et al., 2019).

Behavioral factors are referred to as determinants (Jager and Joachim Mosler, 2007; Dreibelbis et al., 2013) that may immediately influence individual behavior. These are also actions and habits that can be observed directly and factors that influence the mindset of individuals.

\section{Contextual Factors}

Several studies have examined the domain large number of contextual factors (Russell and Fielding, 2010). Stern (2000) finds contextual factors as the second major type of causal variables of environmentally significant behavior after attitude related factors. Contzen and Mosler (2012) state that contextual factors can affect behavior by influencing behavioral factors. In fact various contextual factors influence behavior and individual motivations (Steg and Vlek, 2009; Dietz, 2014) (see Table 4).

In the context of WUE, the contextual factors that have been studied are social, economic, environmental, technical 
TABLE 4 | Examples of contextual factors that influence environmental behavior.

\begin{tabular}{|c|c|c|}
\hline Approach & Factors & Reference \\
\hline $\begin{array}{l}\text { Theory of environmentally significant } \\
\text { behavior }\end{array}$ & $\begin{array}{l}\text { Interpersonal influences; community expectations; advertising; government regulations; legal and } \\
\text { institutional factors; monetary incentives and costs; the physical difficulty of specific actions; } \\
\text { capabilities and constraints provided by technology and the built environment; the availability of } \\
\text { public policies to support behavior; social, economic, and political context }\end{array}$ & Stern, 2000 \\
\hline Environmental psychology & Physical infrastructure, technical facilities, the availability of products, and product characteristics & Steg and Vlek, 2009 \\
\hline $\begin{array}{l}\text { Water, sanitation, and hygiene } \\
\text { behavior (WASH) }\end{array}$ & Social, physical, and personal & Contzen and Mosler, 2012 \\
\hline
\end{tabular}

(Jorgensen et al., 2009; Millock and Nauges, 2010; Russell and Fielding, 2010; Lee et al., 2011; Willis et al., 2013; Scott et al., 2014; Jorge et al., 2015; Wang et al., 2015; Hussien and Memon, 2016; Vieira et al., 2017; Kneebone et al., 2018; Nazari et al., 2018; Benedict and Hussein, 2019; Kapetas et al., 2019; Koh, 2020) and, in some cases institutional factors.

\section{Socioeconomic Factors}

Factors such as age (Beal et al., 2013; Tang et al., 2013; Attari, 2014; Chang et al., 2016; Dean et al., 2016; Piedra-Muñoz et al., 2018; Khair et al., 2019), gender (Beal et al., 2013; Attari, 2014; Piedra-Muñoz et al., 2018), education level (Beal et al., 2013; Chang et al., 2016; Dean et al., 2016; Piedra-Muñoz et al., 2018; Khair et al., 2019), information (Dean et al., 2016), networking (Tang et al., 2013; Dean et al., 2016), household characteristics (Russell and Fielding, 2010; Dreibelbis et al., 2013), and population density (Benito et al., 2019; Zhang and Xu, 2019) are the key socio-demographic factors that contextualize water use.

Age, education level, information, and networking are strongly associated with knowledge (Dean et al., 2016) about water use, which is a core component of solving waterrelated problems.

Some authors have shown that men and women differ in terms of environmental awareness (Piedra-Muñoz et al., 2018), and risk perception (Attari, 2014). Meanwhile, cultural factors involve beliefs and traditions that influence water use practices. For instance, Kadibadiba et al. (2018) observed that high levels of domestic consumption are associated with the daily desire for cleanness, comfort, and convenience in certain cultures. Household size and composition are linked with economic capability to make investments, e.g., on water saving devices; while population density influences the operation and performance of water utilities due to economies of scale, resulting from consequent size of utilities (Benito et al., 2019).

Financial incentives include subsidies that may have positive or negative effects on WUE. There are subsidies to conserve water, investments in technology and infrastructure; others such as subsidized energy mainly has promoted groundwater overuse (Nazari et al., 2018; Khair et al., 2019). This incentive has thus had the opposite effect, known as the rebound effect (FreireGonzález, 2019).

Water pricing is a relevant determinant since it affects perceptions (Tang et al., 2013), willingness (Bruneau et al., 2013), awareness, and attitudes (Nazari et al., 2018) of water users such as farmers and households. This together with other factors signals people to use water efficiently. The regional economy also influences technical factors, such as training, investment in infrastructure or ability to acquire water savings devices (Bruneau et al., 2013). Several economic activities, such as agriculture, depend on water to produce goods, and its productivity is often associated with average income of the producers (Graymore et al., 2010; Khair et al., 2019; Xiao et al., 2019), and diversification of the economy. For instance, if irrigated agriculture is the only source of livelihood (i.e., lack of diversification), water users will focus solely on increasing production to increase profits (Roobavannan et al., 2017; Khair et al., 2019), leading to a higher water demand (Ghanim, 2019; Xiao et al., 2019). In such cases, users may not adopt techniques to increase WUE if water is not appropriately priced, or may adopt low flow high-efficiency faucets like drip irrigation but still consume more water (so called efficiency paradox), since their perception of well-being is driven by profit maximization.

\section{Technical Factors}

Frequently examined technical factors include training, data availability, elaboration of WUE plans, infrastructure and technology readiness, and the performance of utilities in terms of financial and NRW indicators, and capacity to supply water demand. Training facilitates a better understanding of water usage and knowledge of good water management practices (Dean et al., 2016; Nazari et al., 2018) and better informed decisions. The metering and monitoring of water use are often overlooked. Also, flawed estimations of water requirements, water balance, and allocation (Manouseli et al., 2019), and management of water systems (Benito et al., 2019) can lead to water use inefficiency. Timely and accurate information is therefore required to plan and implement efficient use of water (Manouseli et al., 2019).

The infrastructure of a water system also impacts WUE. Proper pricing and financial sustainability can lead to more capacity for investments (Ding et al., 2019; Manouseli et al., 2019), and proper operation (Nazari et al., 2018), and maintenance. In some water systems, the operations have to be stopped because of reasons such as water scarcity, and water contamination. As a result, there are water restrictions, e.g., shortages and intermittent supply. Such circumstances can motivate users to adopt water savings measures (Graymore et al., 2010) but can also have serious implications for efficient operations and water use (Charalambous and Laspidou, 2017). 


\section{Institutional and Environmental Factors}

There are three groups of functions that water related institutions are generally responsible for. First concerns the goals to guide, enable, and constrain the actions of individuals (Greif, as cited in Vitola and Senfelde, 2015), firms, households, and other decision-making units (Lynne et al., 1991), and shaping human interactions around water use (North as cited in Vitola and Senfelde, 2015). These may activate values and shape beliefs of individuals and can change the behavior of many toward water use (Stern, 2000). The second group of functions focuses on coordinating activities (Geels, 2004), and designing, and implementing policies systematically (Kapetas et al., 2019). The third group of functions facilitates information and promotes incentives to encourage people to use water appropriately (Ostrom, 1990; Aligica, 2006; Koehler et al., 2018).

Individual staff members are crucial stakeholders along the chain of water use decisions and actions (Meglino and Ravlin, 1998). The structure of institutions itself (Ortigara et al., 2018) determines the progress and implementation of regulations. For example, populist agendas rarely prioritize WUE. At the same time, unstable water governance (Ortigara et al., 2018) interrupts planning activities, and lack of environmental awareness policies becomes a hurdle to implement WUE measures promptly.

The influence of institutions on behavior has been often highlighted (Markey-towler, 2018). Jorgensen et al. (2009). Graymore et al. (2010) argue that trust in institutions is linked to water-saving by water users. If water users do not trust the institutions, they are less likely to use water efficiently. Additionally, weak institutions produce ineffective regulations and subsequently do not encourage users to use water efficiently (Khair et al., 2019).

Regulations often lag behind the understanding of current and future water challenges (Nazari et al., 2018) with little participation of stakeholders (Chang et al., 2016). The involvement of communities is important, but often ignored, in the design and application of rules and regulations (Horinkova and Abdullaev, 2003), because it influences their attitudes toward the implemented regulations, awareness of beneficial consequences, and willingness to obey (Chang et al., 2016).

\section{Behavioral Factors}

Behavioral factors consist of perceptions, thoughts, feelings, and beliefs that affect the practice of behavior. These factors as a whole characterize the mindset of an individual linked to behavior (Contzen and Mosler, 2012).

Several theories and models have been used to analyze environmental behavior such as the norm activation model (NAM) (Steg and de Groot, 2018); the new environmental paradigm (NEP) (Dunlap et al., 2000); the theory of planned behavior (TPB) (Ajzen, 1991); the theory of values (Steg and de Groot, 2018); the values, beliefs, and norms theory (VBN) (Stern, 2000; Yildirim and Semiz, 2019); the theory of environmentally significant behavior (Stern, 2000); and the risk, attitude, norms, abilities, and self-regulation (RANAS) model (Contzen and Mosler, 2012) (see Table 5).

The RANAS model combines the most important behavioral theories to explain and change behavior (Contzen and Mosler,
2012). It has two main advantages, firstly, it can be adapted to a range of behaviors in a variety of settings and populations, and it provides a standard template of questions to quantify behavioral factors and analyze the behavior. This further allows the comparison of multiple sites or scenarios (Dreibelbis et al., 2013). Risk, attitude, norms, abilities, and self-regulation has been used to evaluate behaviors linked to water, sanitation, and hygiene (WASH) practices, such as handwashing and adoption of household water treatment technology (Contzen and Mosler, 2012; Mosler, 2012; Dreibelbis et al., 2013; Lilje and Mosler, 2018; Daniel et al., 2019; Nunbogu et al., 2019). In the context of water use, RANAS factors such as knowledge, beliefs, and emotions are linked to an individual's psychology of water use and influence the practice of a behavior (Mosler and Contzen, 2016). Indeed, this model includes behavioral factors such as risk, and self-regulation that are crucial to regulate and understand different behaviors.

One of the theories that has been integrated in the RANAS is the TPB, which has also been widely used to investigate and understand environmental behaviors, including water use and its associated factors (Harland et al., 1999; Stern, 2000; Steg and Vlek, 2009; Russell and Fielding, 2010; Mosler, 2012; Fu and Wu, 2014; Yuriev et al., 2020).

Values are defined as "concepts or beliefs about desirable end states or behaviors that transcend specific situations and guide the evaluation of behavior and are ordered by relative importance" (Dietz et al., 2005, p. 345-346). Values may directly affect beliefs, norms and behavior. Beliefs have a direct effect on norms and norms influence behavior (Roobavannan et al., 2018). In the domain of environmental behavior, values are factors that are linked with concern about the environment and may affect individual decisions. These are altruism, biospheric, egoistic, and hedonistic values (Stern, 2000; Dietz et al., 2005; Steg and de Groot, 2018). Personal norms are a solid base for predispositions of individuals to pro-environmental action (Stern, 2000).

Stern (2000) integrated the values theory, NEP and NAM to developed the VBN theory of environmentalism. It is represented by a causal chain that includes values, beliefs and norms and its variables (Stern, 2000; Dietz et al., 2005) (see Figure 1).

Since individual behavior is essential to analyse the psychology of why people use water efficiently or not, behavioral studies have mainly focused on individual users, e.g., how consumers react to WUE measures and regulations (Graymore and Wallis, 2010; Lee et al., 2011; Scott et al., 2014; Jorge et al., 2015; Wang et al., 2015; Vieira et al., 2017; Kneebone et al., 2018; Nazari et al., 2018; Benedict and Hussein, 2019; Kapetas et al., 2019; Koh, 2020). Several stakeholders, including farmers and households from rural communities have been considered.

\section{KNOWLEDGE GAPS IN UNDERSTANDING WUE}

Limited number of studies (Cortner et al., 1998; Chai and Schoon, 2016; Nazari et al., 2018; Kapetas et al., 2019) have considered stakeholders such as the institutions and their staff in assessing WUE. The determinants of individual behavior 
TABLE 5 | Models and theories and factors to understand environmental behavior.

\begin{tabular}{|c|c|c|}
\hline Model or theory & Approach & Factors \\
\hline The norm activation model (NAM) [1] & $\begin{array}{l}\text { The pro-environmental actions follow from the activation of personal norms, } \\
\text { reflecting feelings of moral obligation to perform actions. Experimental studies } \\
\text { have showed that NAM variables are causally related. }\end{array}$ & $\begin{array}{l}\text { Personal norms are activated by: problem } \\
\text { awareness; ascription of responsibility; } \\
\text { outcome efficacy; self-efficacy }\end{array}$ \\
\hline $\begin{array}{l}\text { The new environmental paradigm } \\
\text { (NEP) }[2,3]\end{array}$ & $\begin{array}{l}\text { The NEP focused on beliefs about humanity's ability to upset the balance of } \\
\text { nature, the existence of limits to growth for human societies, and humanity's right } \\
\text { to rule over the rest of nature. }\end{array}$ & Beliefs \\
\hline Theory of planned behavior (TPB) [1] & $\begin{array}{l}\text { Behavior results from the intention to engage in specific behavior. } \\
\text { The TPB assumes that socio-demographics and values influence behavior } \\
\text { indirectly via attitudes, subjective norms, and perceived behavioral. } \\
\text { Attitudes express a positive or negative stance toward a behavior; subjective } \\
\text { norms, normative factors represent convictions about the incidence of a } \\
\text { behavior and how the social network thinks about the behavior; perceived } \\
\text { behavioral control ability factors represent the aptitudes and individual beliefs. }\end{array}$ & $\begin{array}{l}\text { Attitudes, subjective norms, and } \\
\text { perceived behavioral }\end{array}$ \\
\hline Theory of values [1] & $\begin{array}{l}\text { Values include beliefs about desirability or undesirability of certain end-states that } \\
\text { transcend specific situations. Values serve as guideline principles for the } \\
\text { evaluation of people and for behaviors. }\end{array}$ & $\begin{array}{l}\text { Key values for pro-environmental behavior. } \\
\text { These are separated in two dimensions: } \\
\text { Self-transcendence: altruistic; biospheric. } \\
\text { Self-enhancement; egoistic and hedonic. }\end{array}$ \\
\hline $\begin{array}{l}\text { The theory of environmentally } \\
\text { significant behavior [4] }\end{array}$ & $\begin{array}{l}\text { This theory assesses the definitions, classifies the precursors of environmental } \\
\text { behavior, evaluates the links between environmental concern and behavior and } \\
\text { identifies the factors that determinate environmentally significant behavior. }\end{array}$ & $\begin{array}{l}\text { Causal variables: attitudinal; personal } \\
\text { capabilities; contextual factors; habit } \\
\text { and routine. }\end{array}$ \\
\hline $\begin{array}{l}\text { The value-belief-norm theory (VBN) } \\
{[1,3,4,5,6]}\end{array}$ & $\begin{array}{l}\text { This theory is an extension of the NAM and links the values theory, the norm } \\
\text { activation theory (NAM) and new environmental paradigm (NEP). } \\
\text { A causal chain of values (biospheric, altruistic, and egoistic), beliefs, and } \\
\text { personal norms triggers the behavior. } \\
\text { Beliefs consist of personal worldview of concerns or perceptions about the } \\
\text { consequences of human actions that may harm the environment; norms relate to } \\
\text { moral obligations to engage in an environmental behavior; values are central to } \\
\text { any decision making process, and guide behavior and attitudes. }\end{array}$ & $\begin{array}{l}\text { Values; beliefs on relationships between } \\
\text { humans and the natural environment } \\
\text { reflected by ecological worldview; norms }\end{array}$ \\
\hline $\begin{array}{l}\text { Risk, attitude, norm, abilities, } \\
\text { self-regulation (RANAS) }[1,5]\end{array}$ & $\begin{array}{l}\text { This model systematically identifies, measures, and integrates behavioral and } \\
\text { contextual factors to assess behavior at an individual scale. } \\
\text { The RANAS model derives the factors on the basis of quantitative data. } \\
\text { Behavioral outcomes: behavior; intention and habit. } \\
\text { Risk: perceived vulnerability. } \\
\text { Attitude: instrumental beliefs, affective beliefs. } \\
\text { Normative: descriptive, injunctive, and personal norms. } \\
\text { Ability: action knowledge, self-efficacy, maintenance efficacy, recovery efficacy. } \\
\text { Self-regulation: action control/planning, coping planning, } \\
\text { remembering, commitment. }\end{array}$ & Risk; attitude; ability; self-regulation. \\
\hline
\end{tabular}

[1] (Steg and de Groot, 2018); [2] (Dunlap and Van Liere, 2010); [3] (Russell and Fielding, 2010); [4] (Stern, 2000); [5] (Contzen and Mosler, 2012); [6] (Dietz, 2014).

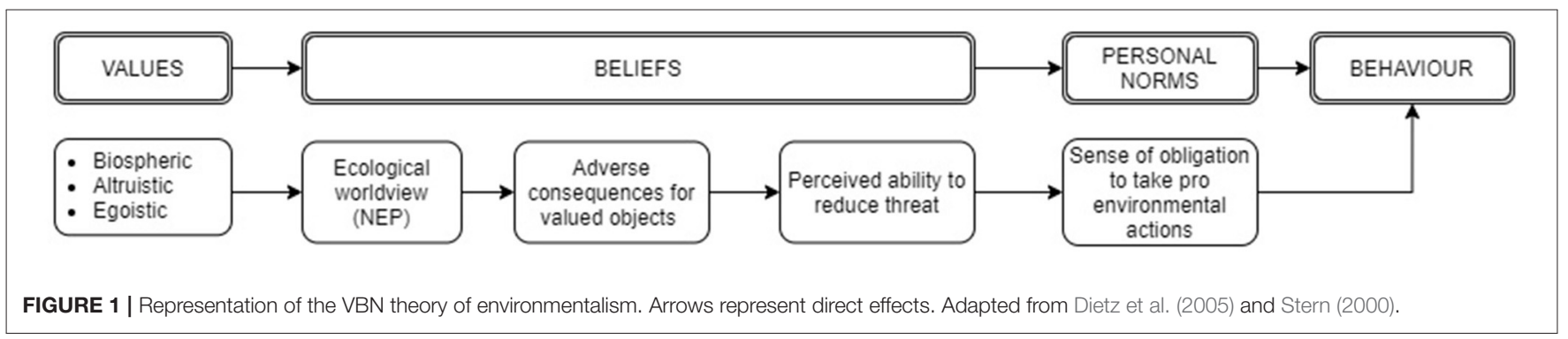

within organizations are different from those of household behaviors and the behavior of organizations has a huge environmental impact. All stakeholders may ignore it. But the disregard for environmental criteria by institutions can have more adverse consequences. For example, institutions may ignore environmental criteria or make decisions regarding the use of water that lead to unknown adverse environmental impacts (Stern, 2000). Such decisions may drive individual behavior (Stern, 2000) within organizations (Meglino and Ravlin, 1998). Moreover, environmental behavior of individuals may be influenced by the actions of organization to which they belong (Stern, 2000).

Few studies have highlighted and incorporated the role of users' trust in institutions and their influence on environmental 


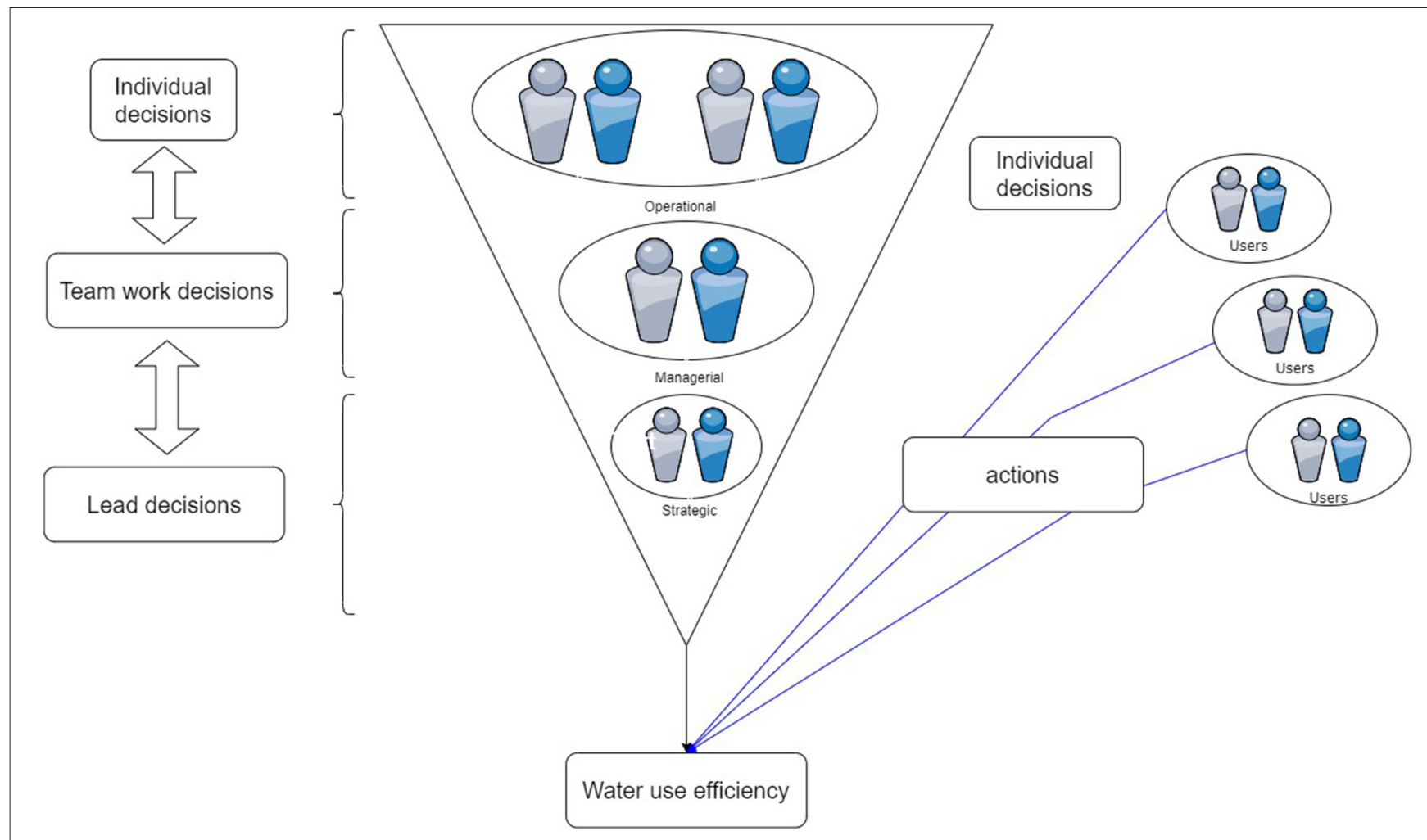

FIGURE 2 | Actors involved in using water (in)efficiently for domestic purposes.

behavior. The specific role that trust plays in determining water efficiency behavior remains unclear (Jorgensen et al., 2009). The actions taken by institutions are a result of a chain of decisions taken by relevant individuals. Subsequently, the psychology and consequent actions of such individuals also alter water use related decisions and measures that institutions take up as a whole.

Assessment of individual perceptions (Meglino and Ravlin, 1998) and the relationships between engaged stakeholders can unravel the influence of institutions over users, and how institutions can work toward WUE targets. This is illustrated in Figure 2. Note that the users can also be influenced by the individuals of institutions given that they frequently interact with each other.

The variables that influence sustainable water use have been widely studied, such as age and incentives (Brown and Keath, 2008; González-Gómez et al., 2011; Wang et al., 2015; Khair et al., 2019). Most of the variables are assumed to independently influence the behavior of water use. Yet many studies have highlighted the need for an integrated view of WUE, indicating its links with the underlying human behavior and institutions (Graymore and Wallis, 2010; Lee et al., 2011; Scott et al., 2014; Jorge et al., 2015; Wang et al., 2015; Vieira et al., 2017; Kneebone et al., 2018; Nazari et al., 2018; Benedict and Hussein, 2019; Kapetas et al., 2019; Koh, 2020).

Therefore, there are three main gaps in our understanding of WUE concerning to human behavior. First, an integrated assessment of behavioral and contextual factors and its relationships in relation to WUE is lacking. Second, the influence of institutions on WUE has not been evaluated completely. Only end users such as households and farmers are acknowledged for their roles in using water (in)efficiently. All other stakeholders in the supply chain of water use are mostly ignored. The influence of institutional stakeholders is neither fully known nor documented. Consumers' trust in institutions is however important to implement WUE measures (Graymore et al., 2010; 2009; Beal et al., 2013; Fu and Wu, 2014; Caspers, 2020). Further, decisions within an institution involve actions of multiple staff members and, therefore, staff dynamics within institutions also play a role in proposing regulations about WUE, of which little is known about its effect on WUE. Finally, a standardized method to understand WUE practices in terms of contextual and behavioral factors is missing.

An integrated approach of stakeholders is therefore needed to move from the current assessment that focuses solely on the behavior of individuals and households as water users to include others stakeholders, especially institutions and how they behave (Stern and Dietz, 2020).

To do that we propose an extension of the RANAS model and integrate it with the VBN theory. The extension consists of including institutions (the organization responsible for water supply system) as an additional contextual factor, and trust as an additional behavioral factor. 


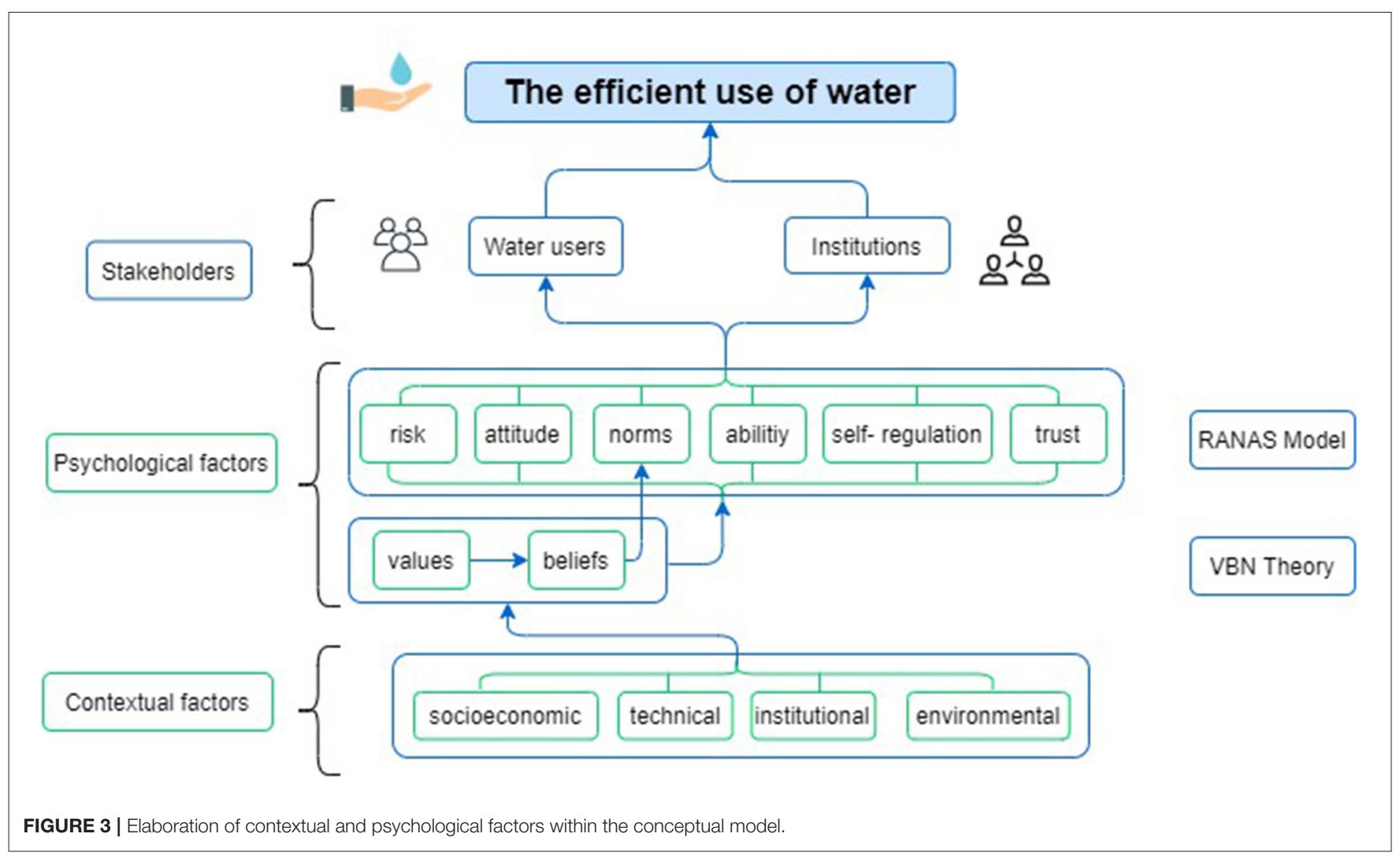

\section{A CONCEPTUAL MODEL TO UNDERSTAND WUE BEHAVIOR}

Existing approaches for measuring and understanding environmental behavior are used as guide and source of inspiration. These include the model of behavior change (Contzen and Mosler, 2012) that has been used for the water and sanitation sector in developing countries (Mosler, 2012); the framework of Steg and Vlek (2009) for understanding and promoting pro-environmental behavior; the research of Carrus et al. (2010) for studying the socio-psychological and contextual predictors to assess sustainable water consumption and the causal chain of factors across the environmental significant behavior (Stern, 2000).

A causal hierarchy of contextual and behavioral factors is assumed, in order to suggest that context affect the psychology and the behavioral factors, which in turn influence the environmental behavior of individuals. All factors together determine the behavioral outcome with respect to efficient use of water. The model has three main components: contextual factors, behavioral (or psychological) factors, and water users, including institutions who are the stakeholders (see Figure 3).

The target behavior is the efficient use of water (WUE). It is a result of psychological processing of factors intrinsic to an individual (Steg and Vlek, 2009; Mosler, 2012), and involves the execution of responsible pro-environmental actions (Hines et al., 1987; Steg and de Groot, 2018). The WUE behavior involves curtailment actions that are associated to resource conservation and efficiency actions that are related with the installation of water efficiency technology (Russell and Fielding, 2010; Beal et al., 2013). These actions can be shorter showers or harvest water by using rain barrels, both having positive impacts on water use due to less water consumption and withdrawals.

The conceptual model provides a structure to construct a quantitative model to measure factors that are based on social science experiments (Voinov and Bousquet, 2010) or are informed by local observations such as social surveys (Argent et al., 2016).

This conceptual model offers to fill the identified gaps in several ways. Based on existing psychological models and theories, such as RANAS and VBN, the model interprets behavior underlying WUE with an extension of the RANAS model to include factors linked to institutions. The model concept also offers a "flexible" method that can be used, modified, or expanded to other water use contexts, e.g., drinking water treatment by rural communities, reuse of water, or harvesting of rain water. Finally, the inclusion of institutional factor also allows the interpretation of water use behavior of individuals of water supply organizations and the relationships between water users and water supply organizations.

To explain and identify the relationships within the conceptual model between factors and their influence on (in)efficient water use, the factors and WUE need to be quantified. For this a group of variables are identified for each factor, e.g., socio-demographic variables, attitude, and perception variables, and water use and availability. These variables can 
then be quantified using RANAS inspired questionnaires (Daniel et al., 2019), interviews, and field measurements of water use and supply (e.g., rainfall) fluxes.

\section{CONCLUSIONS}

The success of various efforts at implementing WUE measures has been limited by several related reasons. One cause behind higher than expected demand and inefficient use of water is human behavior and therefore related to the lack of an integrated assessment of behavioral and contextual factors that influence water use behavior.

Based on an extensive review, the paper identified a variety of contextual and psychological factors underlying the behavior. A conceptual model, based on existing models and theories, was proposed that integrates both groups of factors and proposes relationships between water users and institutions to understand (in)efficient water use. Involving water managers facilitates the assessment of institutional relationships between water users and water managers. This will unravel the influence of institutions or organizations on the behavior of water users, and vice versa.

Local observations and social surveys should provide the data that are needed to populate the model and test factors influencing the behavior.

The paper further highlighted that water users and institutions involved in the water use chain have an important role

\section{REFERENCES}

Ajzen, I. (1991). The theory of planned behavior. Organ. Behav. Hum. Decis. Process. 50, 179-211. doi: 10.4135/9781446249215.n22

Aligica, P. D. (2006). Institutional and stakeholder mapping: frameworks for policy analysis and institutional change. Publ. Organ. Rev. 6, 79-90. doi: 10.1007/s11115-006-6833-0

Argent, R. M., Sojda, R. S., Guipponi, C., McIntosh, B., Voinov, A. A., and Maier, H. R. (2016). Best practices for conceptual modelling in environmental planning and management. Environ. Model. Softw. 80, 113-121. doi: 10.1016/j.envsoft.2016.02.023

Arto, I., Andreoni, V., and Rueda-cantuche, J. M. (2016). Global use of water resources : a multiregional analysis of water use, water footprint and water trade balance. Water Resour. Econ. 15, 1-14. doi: 10.1016/j.wre.2016.04.002

Attari, S. Z. (2014). Perceptions of water use. Proc. Natl. Acad. Sci. U.S.A. 111, 5129-5134. doi: 10.1073/pnas.1316402111

Beal, C. D., Stewart, R. A., and Fielding, K. (2013). A novel mixed method smart metering approach to reconciling differences between perceived and actual residential end use water consumption. J. Clean. Prod. 60, 116-128. doi: 10.1016/j.jclepro.2011.09.007

Benedict, S., and Hussein, H. (2019). An analysis of water awareness campaign messaging in the case of Jordan: water conservation for state security. Water 11:1156. doi: 10.3390/w11061156

Benito, B., Faura, Ú., Guillamón, M. D., and Ríos, A. M. (2019). Empirical evidence for efficiency in provision of drinking water. J. Water Resour. Plann. Manage. 145, 1-10. doi: 10.1061/(ASCE)WR.1943-5452.0001049

Bhaduri, A., Bogardi, J., Siddiqi, A., Voigt, H., Vörösmarty, C., Pahl-Wostl, C., et al. (2016). Achieving sustainable development goals from a water perspective. Front. Environ. Sci. 4:64. doi: 10.3389/fenvs.2016.00064

Brooks, D. B. (2006). An operational definition of water demand management. Int. J. Water Resour. Dev. 22, 521-528. doi: 10.1080/0790062060077 9699 to play in making decisions and taking actions that affect WUE. Often the focus on end users such as households means that other stakeholders in the supply chain of water use are mostly ignored, such as institutional stakeholders (organizations/water managers). Linking the knowledge of WUE with stakeholder's perceptions, would, as a result, contribute to a more comprehensive assessment of WUE.

\section{AUTHOR CONTRIBUTIONS}

DC drafted, revised, and finalized the paper. SP and LR edited the paper. All authors contributed to the ideas in the paper and agreed to the submitted form.

\section{FUNDING}

DC is funded by Pasaporte a la Ciencia programme of Instituto Colombiano de Crédito Educativo y Estudios Técnicos en el Exterior-ICETEX.

\section{ACKNOWLEDGMENTS}

The authors would like to thank D. Daniel, Melissa Haeffner, Juan Pablo Rodriguez, and Anjana Ekka, and for their insights and comments on earlier drafts of the paper.

Brown, R. R., and Keath, N. A. (2008). Drawing on social theory for transitioning to sustainable urban water management: turning the institutional supertanker. Aust. J. Water Resour. 12, 73-83. doi: 10.1080/13241583.2008.1146 5336

Bruneau, J., Dupont, D., and Renzetti, S. (2013). Economic instruments, innovation, and efficient water use. Canad. Publ. Policy 39, S11-S22. doi: 10.3138/CPP.39.Supplement2.S11

Carrus, G., Bonnes, M., Corral-verdugo, V., Moser, G., and Sinha, J. (2010). "Social-psychological and contextual predictors of sustainable water consumption," in Psychological Approaches to Sustainability: Current Trends in Theory, Research and Applications, 415. Available online at: https://www. scopus.com/inward/record.uri?partnerID $=\mathrm{HzOxMe} 3$ b\&scp $=84892019381 \&$ origin=inward (Retrieved March 10, 2021).

Caspers, C. G. W. (2020). Role of trust in adopting consumer social responsible behaviour in the context of water use in domestic households. South East Eur. J. Econ. Bus. 15, 1-13. doi: 10.2478/jeb-2020-0001

Chai, Y., and Schoon, M. (2016). Institutions and government efficiency: decentralized irrigation management in China. Int. J. Commons 10, 21-44. doi: 10.18352/ijc.555

Chang, G., Wang, L., Meng, L., and Zhang, W. (2016). Farmers' attitudes toward mandatory water-saving policies: a case study in two basins in northwest China. J. Environ. Manage. 181, 455-464. doi: 10.1016/j.jenvman.2016.07.007

Charalambous, B., and Laspidou, C. (2017). Dealing with the Complex Interrelation of Intermittent Supply and Water Losses. Scientific and Technical Report. London: IWA Publishing.

Cole, M. J., Bailey, R. M., Cullis, J. D. S., and New, M. G. (2018). Water for sustainable development in the Berg Water Management Area, South Africa. South Afr. J. Sci. 114, 1-10. doi: 10.17159/sajs.2018/20170134

Contzen, N., and Mosler, H.-J. (2012). “The Risks, Attitudes, Norms, Abilities, and Self-regulation (RANAS) approach to systematic behavior change," in Eawag. Available online at: https://www.eawag.ch/en/department/ess/ (Retrieved April 20, 2020). 
Cortner, H. J., Wallace, M. G., Burke, S., and Moote, M. A. (1998). Institutions matter: the need to address the institutional challenges of ecosystem management. Landsc. Urban Plan. 40, 159-166. doi: 10.1016/S0169-2046(97)00108-4

Daniel, D., Diener, A., Pande, S., Jansen, S., Marks, S., Meierhofer, R., et al. (2019). Understanding the effect of socio-economic characteristics and psychosocial factors on household water treatment practices in rural Nepal using Bayesian Belief Networks. Int. J. Hyg. Environ. Health 222, 847-855. doi: 10.1016/j.ijheh.2019.04.005

Dean, A. J., Fielding, K. S., and Newton, F. J. (2016). Community knowledge about water: who has better knowledge and is this associated with water-related behaviors and support for water-related policies? PLOS ONE 11:e0159063. doi: 10.1371/journal.pone.0159063

Department of Agriculture, Water and the Environment (2019). National Water Initiative (NWI). Retrieved from Department of Agriculture, Water and the Environment. Available online at: https://www.agriculture.gov.au/water/ policy/nwi

Dietz, T. (2014). Understanding environmentally significant consumption. Proc. Natl. Acad. Sci. U.S.A. 111, 5067-5068. doi: 10.1073/pnas.14031 69111

Dietz, T., Fitzgerald, A., and Shwom, R. (2005). Environmental values. Annu. Rev. Environ. Resour. 30, 335-372. doi: 10.1146/annurev.energy.30.050504.1 44444

Ding, X., Zhang, Z., Wu, F., and Xu, X. (2019). Study on the evolution ofwater resource utilization efficiency in Tibet autonomous region and four provinces in Tibetan areas under double control action. Sustainability 11:3396. doi: $10.3390 /$ SU11123396

Dreibelbis, R., Winch, P., Leontsini, E., Hulland, K. R., Ram, P. K., Unicomb, L., et al. (2013). The integrated behavioural model for water, sanitation, and hygiene: a systematic review of behavioural models and a framework for designing and evaluating. BMC Public Health 13:1015. doi: 10.1186/1471-2458-13-1015

Dunlap, R. E., and Van Liere, K. D. (2010). The "new environmental paradigm." J. Environ. Educ. 49, 19-28. doi: 10.3200/JOEE.40.1.19-28

Dunlap, R. E., Van Liere, K. D., Mertig, A. G., and Jones, R. E. (2000). New trends in measuring environmental attitudes: measuring endorsement of the new ecological paradigm: a revised NEP scale. J. Soc. Issues 56, 425-442. doi: 10.1111/0022-4537.00176

EEA (2007). Towards Efficient Use of Water Resources in Europe 212. European Environment Agency.

EPA (2018). WaterSense. United States Environmental Protection Agency. Available online at: https://www.epa.gov/watersense/how-we-use-water\#Daily $\% 20$ Life

EU (2014). EU Resource Efficiency Scoreboard, 2014 Highlights. European Union. Enviroment European Commission.

European Union (2019). Water Exploitation Index-Eurostat - Productos Datasets. Available online at: https://ec.europa.eu/eurostat/web/main/home

FAO (2018a). Step by Step Monitoring of Change in Water Use Efficiency Over Time. Progress on Water Use Efficiency - Global Baseline for SDG 6 Indicator 6.4.1. Available online at: https://www.unwater.org/publications/progress-on-wateruse-efficiency-641/ (accessed August 22, 2019).

FAO (2018b). Food and Agriculture Organization of the United Nations. Sustainable Development Goals. Available online at: http://www.fao.org/3/CA1588EN/ ca1588en.pdf

FAO (n.d.). AQUASTAT - FAO's Global Information System on Water and Agriculture. Available online at: http://www.fao.org/aquastat/en/overview/ methodology/water-use

Freire-González, J. (2019). Does water efficiency reduce water consumption? The economy-wide water rebound effect. Water Resour. Manage. 33, 2191-2202. doi: 10.1007/s11269-019-02249-0

$\mathrm{Fu}, \mathrm{Y}$., and $\mathrm{Wu}, \mathrm{W}$. (2014). "Behaviour interventions for water end use: an integrated model," in ICAC 2014 - Proceedings of the 20th International Conference on Automation and Computing: Future Automation, Computing and Manufacturing. ICAC, 14. University of Strathclyde Press (Strathclyde).

GAO-14-430 (2014). Supply Concerns Continue, and Uncertainties Complicate Planning. Report to Congressional Requesters. Available online at: https://www. gao.gov/assets/gao-14-430.pdf
Geels, F. W. (2004). From sectoral systems of innovation to socio-technical systems: insights about dynamics and change from sociology and institutional theory. Res. Policy 33, 897-920. doi: 10.1016/j.respol.2004.01.015

Ghanim, A. A. (2019). Water resources crisis in Saudi Arabia, challenges and possible management options: an analytic review. World Acad Sci. Eng. Technol. 13, 51-56. doi: 10.5281/ZENODO.2571928

Glavič, P., and Lukman, R. (2007). Review of sustainability terms and their definitions. J. Clean. Prod. 15, 1875-1885. doi: 10.1016/j.jclepro.2006.12.006

Gleick, P. H., Christian-Smith, J., and Cooley, H. (2011). Water-use efficiency and productivity: rethinking the basin approach. Water Int. 36, 784-798. doi: 10.1080/02508060.2011.631873

González-Gómez, F., García-Rubio, M. A., and Guardiola, J. (2011). Why is nonrevenue water so high in so many cities? Int. J. Water Resour. Dev. 27, 345-360. doi: 10.1080/07900627.2010.548317

Graymore, M., Wallis, A., and O’Toole, K. (2010). Understanding drivers and barriers: the key to water use behaviour change. Water Sci. Technol. 10, 679-688. doi: 10.2166/ws.2010.125

Graymore, M. L. M., and Wallis, A. M. (2010). Water savings or water efficiency? Water-use attitudes and behaviour in rural and regional areas. Int. J. Sustain. Dev. World Ecol. 17, 84-93. doi: 10.1080/13504500903497249

Hák, T., Janoušková, S., and Moldan, B. (2016). Sustainable development goals: a need for relevant indicators. Ecol. Indic. 60, 565-573. doi: 10.1016/j.ecolind.2015.08.003

Harland, P., Staats, H., and Wilke, H. A. M. (1999). Explaining proenvironmental intention and behavior by personal norms and the theory of planned behavior. J. Appl. Soc. Psychol. 29, 2505-2528. doi: 10.1111/j.1559-1816.1999.tb 00123.x

Hens, L., Block, C., Cabello-Eras, J. J., Sagastume-Gutierez, A., GarciaLorenzo, D., Chamorro, C., et al. (2018). On the evolution of "Cleaner Production" as a concept and a practice. J. Clean. Prod. 172, 3323-3333. doi: 10.1016/j.jclepro.2017.11.082

Hines, J. M., Hungerford, H. R., and Tomera, A. N. (1987). Analysis and synthesis of research on responsible environmental behavior: a meta-analysis. J. Environ. Educ. 18, 1-18. doi: 10.1080/00958964.1987.9943482

Hoekstra, A. Y. (2014). Sustainable, efficient, and equitable water use: the three pillars under wise freshwater allocation. Wiley Interdisciplin. Rev. Water 1, 31-40. doi: 10.1002/wat2.1000

Hoekstra, A. Y., Chapagain, A. K., and van Oel, P. R. (2017). Advancing water footprint assessment research: challenges in monitoring progress towards sustainable development goal 6. Water 9:438. doi: 10.3390/w9060438

Hofste, R. W., Reig, P., and Schleifer, L. (2019). 17 Countries, Home to One-Quarter of the World's Population, Face Extremely High Water Stress [World Resources Institute]. Available online at: https://www.wri.org/insights/17-countrieshome-one-quarter-worlds-population-face-extremely-high-water-stress (Retrieved November 1, 2019).

Horinkova, V., and Abdullaev, I. (2003). Institutional aspects of water management in Central Asia: water users associations. Water Int. 28, 237-245. doi: 10.1080/02508060308691689

Howell, T. A. (2005). "Enhancing WUE in irrigated agriculture," in World Water Congress 2005: Impacts of Global Climate Change - Proceedings of the 2005 World Water and Environmental Resources Congress (Anchorage, AK), p. 524. doi: 10.1061/40792(173)524

Hussien, W. A., and Memon, F. A. (2016). Assessing and modelling the influence of household characteristics on per capita water consumption. Water Resour. Manage. 30, 2931-2955. doi: 10.1007/s11269-016-1314-x

Jabari, S. J. (2017). Non-revenue water management in Palestine. World Acad. Sci. Eng. Technol. 11, 953-959. doi: 10.5281/zenodo.1131505

Jager, W., and Joachim Mosler, H. (2007). Simulating human behavior for understanding. J. Soc. Issues 63, 97-116. doi: 10.1111/j.1540-4560.2007.00498.x

Jorge, C., Vieira, P., Rebelo, M., and Covas, D. (2015). Assessment of water use efficiency in the household using cluster analysis. Proc. Eng. 119, 820-827. doi: 10.1016/j.proeng.2015.08.945

Jorgensen, B., Graymore, M., and O'Toole, K. (2009). Household water use behavior: an integrated model. J. Environ. Manage. 91, 227-236. doi: 10.1016/j.jenvman.2009.08.009

Jorgensen, B. S., and Martin, J. F. (2015). Understanding farmer intentions to connect to a modernised delivery system in an Australian irrigation 
district: a reasoned action approach. J. Environ. Plann. Manage. 58, 513-536. doi: 10.1080/09640568.2013.864620

Kadibadiba, T., Roberts, L., and Duncan, R. (2018). Living in a city without water: a social practice theory analysis of resource disruption in Gaborone, Botswana. Global Environ. Change 53, 273-285. doi: 10.1016/j.gloenvcha.2018.10.005

Kapetas, L., Kazakis, N., Voudouris, K., and McNicholl, D. (2019). Water allocation and governance in multi-stakeholder environments: insight from Axios Delta, Greece. Sci. Total Environ. 695:133831. doi: 10.1016/j.scitotenv.2019.133831

Khair, S. M., Mushtaq, S., Reardon-Smith, K., and Ostini, J. (2019). Diverse drivers of unsustainable groundwater extraction behaviour operate in an unregulated water scarce region. J. Environ. Manage. 236, 340-350. doi: 10.1016/j.jenvman.2018.12.077

Kneebone, S., Fielding, K., and Smith, L. (2018). It's what you do and where you do it: perceived similarity in household water saving behaviours. J. Environ. Psychol. 55, 1-10. doi: 10.1016/j.jenvp.2017.10.007

Koehler, J., Rayner, S., Katuva, J., Thomson, P., and Hope, R. (2018). A cultural theory of drinking water risks, values and institutional change. Global Environ. Change 50, 268-277. doi: 10.1016/j.gloenvcha.2018. 03.006

Koh, Y. T. R. (2020). Attitude, behaviour and choice: the role of psychosocial drivers in water demand management in Singapore. Int. J. Water Resour. Dev. 36, 69-87. doi: 10.1080/07900627.2019.1617114

Lee, M., Tansel, B., and Balbin, M. (2011). Influence of residential water use efficiency measures on household water demand: a four year longitudinal study. Resour. Conserv. Recycl. 56, 1-6. doi: 10.1016/j.resconrec.2011.08.006

Lilje, J., and Mosler, H. J. (2018). Effects of a behavior change campaign on household drinking water disinfection in the Lake Chad basin using the RANAS approach. Sci. Total Environ. 619-620, 1599-1607. doi: 10.1016/j.scitotenv.2017.10.142

Lund, J., Medellin-Azuara, J., Durand, J., and Stone, K. (2018). Lessons from California's 2012-2016 drought. J. Water Resour. Plann. Manage. 144, 1-13. doi: 10.1061/(ASCE)WR.1943-5452.0000984

Lynne, G. D., Shonkwiler, J. S., and Wilson, M. E. (1991). Water permitting behavior under the 1972 Florida Water Resources Act. Land Econ. 67, 340-351. doi: $10.2307 / 3146429$

Manouseli, D., Kayaga, S. M., and Kalawsky, R. (2019). Evaluating the effectiveness of residential water efficiency initiatives in england: influencing factors and policy implications. Water Resourc. Manage. 33, 2219-2238. doi: $10.1007 /$ s1 1269-018-2176-1

Markey-towler, B. (2018). Rules, perception and emotion. J. Instit. Econ.15, 381-396. doi: 10.13140/RG.2.2.10321.43363

Meglino, B. M., and Ravlin, E. C. (1998). Individual values in organizations: concepts, controversies, and research. J. Manage. 24, 351-389. doi: 10.1177/014920639802400304

Mekonnen, M. M., and Hoekstra, A. Y. (2016). Sustainability: four billion people facing severe water scarcity. Sci. Adv. 2:e1500323. doi: 10.1126/sciadv.1500323

Mekonnen, M. M., Pahlow, M., Aldaya, M. M., Zarate, E., and Hoekstra, A. Y. (2015). Sustainability, efficiency and equitability of water consumption and pollution in latin America and the Caribbean. Sustainability 7, 2086-2112. doi: $10.3390 /$ su7022086

Millock, K., and Nauges, C. (2010). Household Adoption of Water-Efficient Equipment : The Role of Socio-economic Factors, Environmental To cite this version : HAL Id : halshs-00492291. Centre d' Economie de la Sorbonne Documents de Travail du.

Minambiente (2010). Política Nacional para la Gestión Integral del Recurso Hídrico. Available online at: https://www.minambiente.gov.co/

Minambiente (2018). Guía para el uso eficiente y ahorro del agua. Available online at: https://www.minambiente.gov.co/

Miola, A., and Schiltz, F. (2019). Measuring sustainable development goals performance: how to monitor policy action in the 2030 Agenda implementation? Ecol. Econ. 164:106373. doi: 10.1016/j.ecolecon.2019.106373

Mosler, H.-J., and Contzen, N. (2016). "Systematic behavior change in water sanitation and hygiene a practical guide using the RANAS approach," in Eawag. Available online at: https://www.eawag.ch/en/department/ess/ (Retrieved April 20, 2020).

Mosler, H. J. (2012). A systematic approach to behavior change interventions for the water and sanitation sector in developing countries: a conceptual model, a review, and a guideline. Int. J. Environ. Health Res. 22, 431-449. doi: 10.1080/09603123.2011.650156
Nazari, B., Liaghat, A., Akbari, M. R., and Keshavarz, M. (2018). Irrigation water management in Iran: implications for water use efficiency improvement. Agric. Water Manage. 208, 7-18. doi: 10.1016/j.agwat.2018.06.003

Nunbogu, A. M., Harter, M., and Mosler, H. J. (2019). Factors associated with levels of latrine completion and consequent latrine use in northern Ghana. Int. J. Environ. Res. Public Health 16:920. doi: 10.3390/ijerph160 60920

Ortigara, A. R. C., Kay, M., and Uhlenbrook, S. (2018). A review of the SDG 6 synthesis report 2018 from an education, training, and research perspective. Water 10:1353. doi: 10.3390/w10101353

Ostrom, E. (1990). Governing the Commons: The Evolution of Institutions for Collective Action. Cambridge: Cambridge University Press. doi: $10.2307 / 3146384$

Piedra-Muñoz, L., Vega-López, L. L., Galdeano-Gómez, E., and ZepedaZepeda, J. A. (2018). Drivers for efficient water use in agriculture: an empirical analysis of family farms in Almería, Spain. Exp. Agric. 54, 31-44. doi: 10.1017/S0014479716000661

Rad, M. H., Sarkheil, H., and Khojastehpour, R. (2019). Analysing water use efficiency and productivity in Iran's metropolises. Proc. Institut. Civil Eng. Water Manage. 172, 102-108. doi: 10.1680/jwama.17.00025

Roobavannan, M., Kandasamy, J., Pande, S., Vigneswaran, S., and Sivapalan, M. (2017). Allocating environmental water and impact on basin unemployment: role of a diversified economy. Ecol. Econ. 136, 178-188. doi: 10.1016/j.ecolecon.2017.02.006

Roobavannan, M.ahendran, Van Emmerik, T. H. M., Elshafei, Y., Kandasamy, J., Sanderson, M. R., Vigneswaran, S., Pande, S., et al. (2018). Norms and values in sociohydrological models. Hydrol. Earth Syst. Sci. 22, 1337-1349. doi: 10.5194/hess-22-1337-2018

Russell, S., and Fielding, K. (2010). Water demand management research: a psychological perspective. Water Resour. Res. 46, 1-12. doi: 10.1029/2009WR008408

Russell, S. V., Knoeri, C., and Russell, S. V. (2020). Exploring the psychosocial and behavioural determinants of household water conservation and intention household water conservation and intention. Int. J. Water Resour. Dev. 36, 940-955. doi: 10.1080/07900627.2019.1638230

Sánchez, T., Luis, D., and Sánchez, T. A. (2004). Uso Eficiente del Agua Agua. Ponencias Sobre Una Perspectiva General Temática. Instituto de Investigación y Desarrollo en Agua Potable, Saneamiento Básico y Conservación del Recurso Hídrico.

Scott, C. A., Vicuña, S., Blanco-Gutiérrez, I., Meza, F., and VarelaOrtega, C. (2014). Irrigation efficiency and water-policy implications for river basin resilience. Hydrol. Earth Syst. Sci. 18, 1339-1348. doi: 10.5194/hess-18-1339-2014

See, K. F. (2015). Exploring and analysing sources of technical efficiency in water supply services: Some evidence from Southeast Asian public water utilities. Water Resour. Econ. 9, 23-44. doi: 10.1016/j.wre.2014.11.002

Stanhill, G. (1986). Water use efficiency. Adv. Agron. 39, 53-85. doi: 10.1016/S0065-2113(08)60465-4

Steg, L., and de Groot, J. I. M. (2018). "Environmental psychology: history, scope, and methods," in Environmental Psychology: An Introduction, 2nd Edn., eds E. M. Steg, and J. I. M. de Groot (Oxford: Wiley-Blackwell), 1-12.

Steg, L., and Vlek, C. (2009). Encouraging pro-environmental behaviour: an integrative review and research agenda. J. Environ. Psychol. 29, 309-317. doi: 10.1016/j.jenvp.2008.10.004

Stern, P. C. (2000). New Environmental theories: toward a coherent theory of environmentally significant behavior. J. Soc. Issues 56, 407-424. doi: 10.1111/0022-4537.00175

Stern, P. C., and Dietz, T. (2020). A broader social science research agenda on sustainability: nongovernmental influences on climate footprints. Energy Res. Soc. Sci. 60:101401. doi: 10.1016/j.erss.2019.101401

Tang, J., Folmer, H., and Xue, J. (2013). Estimation of awareness and perception of water scarcity among farmers in the Guanzhong Plain, China, by means of a structural equation model. J. Environ. Manage. 126, 55-62. doi: 10.1016/j.jenvman.2013.03.051

UN (2015). UN WATER. Water Scarcity. United Nations. Available online at: https://www.unwater.org/water-facts/scarcity/ (accessed August 31, 2020).

Varbanov, P. S., and Walmsley, T. G. (2019). Circular economy and engineering concepts for technology and policy development. Clean Technol. Environ. Policy 21, 479-480. doi: 10.1007/s10098-019-01683-3 
Vieira, P., Jorge, C., and Covas, D. (2017). Assessment of household water use efficiency using performance indices. Resour. Conserv. Recycl. 116, 94-106. doi: 10.1016/j.resconrec.2016.09.007

Vitola, A., and Senfelde, M. (2015). The role of institutions in economic performance. Bus. Theory Pract. 16, 271-279. doi: 10.3846/btp.2015.498

Voinov, A., and Bousquet, F. (2010). Modelling with stakeholders. Environ. Model. Softw. 25, 1268-1281. doi: 10.1016/j.envsoft.2010.03.007

Wang, T., Park, S. C., and Jin, H. (2015). Will farmers save water? A theoretical analysis of groundwater conservation policies. Water Resour. Econ. 12, 27-39. doi: 10.1016/j.wre.2015.10.002

Water footprint (n.d.) What Is a Water Footprint? [Water Footprint Network]. Available online at: https://waterfootprint.org/en/water-footprint/what-iswater-footprint/ (April 2020).

Willis, R. M., Stewart, R. A., Giurco, D. P., Talebpour, M. R., and Mousavinejad, A. (2013). End use water consumption in households: impact of sociodemographic factors and efficient devices. J. Clean. Prod. 60, 107-115. doi: 10.1016/j.jclepro.2011.08.006

Winans, K., Kendall, A., and Deng, H. (2017). The history and current applications of the circular economy concept. Renew. Sustain. Energy Rev. 68, 825-833. doi: 10.1016/j.rser.2016.09.123

Xiao, X., Fan, L., Li, X., Tan, M., Jiang, T., Zheng, L., et al. (2019). Water-use efficiency of crops in the arid area of the middle reaches of the Heihe River: taking Zhangye City as an example. Water 11:1541. doi: 10.3390/w11081541

Yildirim, B. Ç., and Semiz, G. K. (2019). Future teachers' sustainablewater consumption behavior: a test of the value-belief-norm theory. Sustainability 11:1558. doi: 10.3390/su11061558
Yuriev, A., Dahmen, M., Paillé, P., Boiral, O., and Guillaumie, L. (2020). Pro-environmental behaviors through the lens of the theory of planned behavior: a scoping review. Resour. Conserv. Recycl. 155:104660. doi: 10.1016/j.resconrec.2019.104660

Zhang, Y., and Xu, Z. (2019). Efficiency evaluation of sustainable water management using the HF-TODIM method. Int. Trans. Operat. Res. 26, 747-764. doi: 10.1111/itor. 12318

Conflict of Interest: The authors declare that the research was conducted in the absence of any commercial or financial relationships that could be construed as a potential conflict of interest.

Publisher's Note: All claims expressed in this article are solely those of the authors and do not necessarily represent those of their affiliated organizations, or those of the publisher, the editors and the reviewers. Any product that may be evaluated in this article, or claim that may be made by its manufacturer, is not guaranteed or endorsed by the publisher.

Copyright (C) 2021 Callejas Moncaleano, Pande and Rietveld. This is an open-access article distributed under the terms of the Creative Commons Attribution License (CC $B Y)$. The use, distribution or reproduction in other forums is permitted, provided the original author(s) and the copyright owner(s) are credited and that the original publication in this journal is cited, in accordance with accepted academic practice. No use, distribution or reproduction is permitted which does not comply with these terms. 